\title{
Gaps and Challenges in the Enforcement Framework for Consumer Protection in Ethiopia
}

\section{Abstract}

Tessema Elias *

The effectiveness of consumer protection in a market economy is, inter alia, determined by the quality of the enforcement framework of competition law and consumer protection law. Despite Ethiopia's current efforts to bring about an effective consumer protection regime, the country has been experiencing various consumer abuses. This article assesses the gaps and challenges in the existing enforcement schemes for consumer protection in Ethiopia. Common features and practices of effective enforcement strategies and institutional designs for consumer protection, and experiences from some countries based on their success and relevance to Ethiopia are used as benchmarks. It is argued that there is failure to decentralize consumer protection and failure to recognize representation of major stakeholders in the Consumer Protection Authority. Moreover, there is lack of extensive pre-intervention study, failure to give priority to areas of greater consumer risks and failure to take measures against anti-competitive practices. These major gaps and challenges call for empowering and enabling enforcement institutions so that they can work more on the promotion of competition and meanwhile take legal measures against anticompetitive practices.

\section{Key terms}

Consumer protection, enforcement framework, institutional framework, legal framework.

DOI http://dx.doi.org/10.4314/mlr.v9i1.3

\section{Introduction}

In most developed countries, consumer ${ }^{1}$ protection is implemented through the promotion of competition owing to their high level of faith in the benefits of

\footnotetext{
* Tessema Elias (LL.B; LL.M in Business Law); Lecturer-in-Law (Faculty of Law, Hawassa University, Hawassa, Ethiopia); LLM Student in Maritime Law at University of Oslo, Norway; Former Attorney and Consultant at Law. Earlier versions of some themes that are included in this article in their revised and expanded form were presented at Hawassa University Annual Research Review Workshop in May 2015.

1 'Consumer' means a natural person who buys goods and services for his personal or family consumption, where the price is being paid by him or another person and not for
} 
well informed and stable markets to consumers. Less emphasis is thus given to regulatory intervention. In developing market economies, however, there is the need to follow an interventionist approach toward enhancing competition and protecting consumers due to the existence of a high level of market failure. ${ }^{2}$ In fact, developed or efficient market by itself may not necessarily be sufficient to bring about consumer welfare. So, nowadays, most countries have adopted consumer protection laws and institutions.

There is a strong nexus between competition law and consumer protection law. The former focuses on maintaining the process of competition between enterprises and tries to remedy behavioural and structural problems in order to re-establish effective competition in the market the consequences of which are higher economic efficiency, greater innovation, and consumer welfare. ${ }^{3}$ Consumer protection law, on the other hand, is concerned with the nature of consumer transactions by trying to improve market conditions for effective exercise of consumer choice. ${ }^{4}$ Consumer protection law addresses the failings in individual consumer transactions to grant individual consumers remedies ${ }^{5}$. To this end, it fills gaps that market forces leave unfilled. ${ }^{6}$ Thus, the two disciplines focus on different market failures and offer different remedies. Yet, both aim at maintaining well functioning competitive market that promotes consumer welfare. The effectiveness of both laws is, inter alia, determined by the quality of their enforcement framework. ${ }^{7}$ Therefore, maintaining both with a well designed implementation mechanism needs due attention.

Until the enactment of integrated consumer protection law June 8, 2010, consumer issues were addressed under different legislations such as the

manufacture or resale (See Trade Competition and Consumer Protection Proclamation No..813/2014, article 2 (4)).

${ }^{2}$ CUTS, Competition Policy and Consumer Policy, CUTS Discussion paper series No1, India, May, 2003. Lack of adequate information, low level of education, existence of infant or /and non competitive market and existence of gross consumer abuses are among the characteristic features of developing countries which affect consumer choice or rights.

${ }^{3}$ Jaju Kanjo (2005), Recent Development of Consumer Laws in Korea, APEC Information Paper No.6, Korea, May 2005.

${ }^{4}$ Id., p. 5.

${ }^{5}$ Max Huffman (2007), "Competition Law and Consumer Protection", SMU Law Review, Vol.6, No. 4, pp. 103-202, (Southern Methodist University).

${ }^{6}$ Ibid, p. 103

${ }^{7}$ Yassmine Afifi (2008), "Independence of the Egyptian Competition Authority: Assessment and Recommendations", Global Antitrust Review, Voi.6 No. 34, pp. 339-46. Confirming the importance of effective enforcement framework for consumer protection, Afifi noted that "...competition in the market will not be achieved by the mere adoption of competition law, i.e. the existence of a perfectly drafted competition law without its effective enforcement is useless ..." 
Criminal Code, Civil Code, and other specific legislations and were enforced by different institutions. In 2003, Ethiopia introduced Trade Practice Proclamation No. 329/2003 hereinafter called "the former Proclamation" with a view to secure fair competitive process through prevention and elimination of anticompetitive and unfair trade practice, and to safeguard the interest of consumers. ${ }^{8}$ However, due to legal and structural limitations of the Competition Authority ${ }^{9}$ and non inclusion of consumer protection provisions in a right based interventionist manner ${ }^{10}$ it failed to serve its intended purpose.

On June 8, 2010, the Trade Practice and Consumer Protection Proclamation No. 685/2010 hereinafter called "TPCPP" was enacted. It made a comprehensive amendment to the previous proclamation, and it embodies more functional and extensive consumer protection provisions. ${ }^{11}$ On March 21, 2014, a new "Trade Competition and Consumer Protection Proclamation No.813/2014 (TCCP)" was enacted which made some amendments on the TPCPP. ${ }^{12}$ Although the improvements made under the new Proclamation are commendable, there are still serious shortfalls that are left unaddressed. This article attempts to address the challenges pertaining to the institutional framework and the enforcement strategy for consumer protection.

The regulation of consumer protection denotes a body of law designed to protect the interests of consumers at the level of the individual transaction. ${ }^{13}$ Competition law preserves fair competition and it is traditionally conceived as regulation of the market practice to ensure that private conduct does not suppress free trade and competition. ${ }^{14}$ Competition serves to optimize consumers' interests. The two fields share the same ultimate goal (consumer

${ }^{8}$ Article 3 of The Trade Practice Proclamation, Proc. No.329, 2003, Federal Negarit Gazeta, $9^{\text {th }}$ Year No.49

${ }^{9}$ Harka Haroye (2008), "Competition Policy and Laws: Major Concepts and an Overview of Ethiopian Trade Practice Law”, Mizan Law Review, Vol.2, No.1, pp.33-35.

${ }^{10}$ Gebremedhin Braga (2002), "Competition Regime: Capacity Building on Competition Policy in Selected Countries of Eastern and South Africa" 7up3 project.

11 Trade Practice and Consumer Protection Proclamation, Proc. No. 685, 2010, Federal Negarit Gazeta, $16^{\text {th }}$ Year No.49

12 Trade Competition and Consumers Protection Proclamation, Proc. No. 813, 2014, Federal Negarit Gazeta, 20th Year, No. 28.

${ }^{13}$ Nitya, Nanda, Competition Policy and Consumer Protection Policy, Viewpoint Paper for Competition, Investiment and Economic Regulation (CUTS-CCIER) D-218, Bhaskar, Marg, Bani Park, Jaipur 302 016, India, 2005, Available at <www.cuts-international.org> visited on 13 Jan. 2014.

${ }^{14}$ Id., p. 1. 
welfare).$^{15}$ According to Cornelius Dube, competition promotes Static Efficiency which brings about lower prices, better quality, and more choice; it also promotes Dynamic Efficiency which causes (a) efficient allocation of resources, (b) improvements in management, processing and technology, and (c) Product innovation. ${ }^{16}$ All of these objectives of efficiency and their respective outcomes and impact "have consumers as the ultimate beneficiaries and result in satisfaction in trade (consumer welfare)". ${ }^{17}$

Although their approaches to achieving that goal differ ${ }^{18}$ the effectiveness of both laws is highly determined by the quality of enforcement framework. In light of these concepts, the first two sections of this article offer an overview of effective enforcement strategies and institutional design for consumer protection. The third section highlights factors that determine the choice of the design. Sections 4, 5 and 6 briefly deal with the challenges of limited competition, institutional framework and price regulation.

\section{Common Features and Practices of Effective Enforcement Strategies for Consumer Protection}

There is no uniform guiding principle for the adoption and application of effective enforcement strategies and institutional design for consumer protection applicable to all countries across the world. This is due to the difference in socio-economic and political realities exiting among nations in the world. ${ }^{19}$ Thus, countries adjust their consumer protection laws and institutional framework with their respective country-specific socio-economic and political realities. However, there are some common principles that are advocated by various experts in law and economics.

Designing and complying with effective enforcement strategies are central to the success of consumer protection from unfair and abusive market practices. This is due to socio-economic and political set up differences among the nations

\footnotetext{
${ }^{15}$ See Cornelius Dube, Competition Law and Consumer Protection, CUTS Centre for Competition, Investment and Economic Regulation Available at $<$ www.cuts.international.org $>$ last visited on 7 October 2014.

${ }^{16}$ Ibid.

${ }^{17}$ Ibid.

${ }^{18}$ Ibid

19 See World Bank, Building Institutions for Markets, World Development Report: Washington D.C., 2002 According to WB, a survey of 50(fifty) countries' competition laws and their enforcement, conducted for the purpose of world development report 2002, the competition authorities of different countries manifest different features regarding their independence, budget allocation, composition, power and functions and appointment of members of the commission etc. These structural and functional differences (are) observed even among industrial countries.
} 
in the world. ${ }^{20}$ Irrespective of the differences, there are some common socioeconomic and political realities. Thus there are some common enforcement strategies which are advocated by many legal scholars and stakeholders as 'effective designs for consumer protection enforcement', and are adopted by many countries in their consumer protection enforcement framework. ${ }^{21}$ These are: (a) Following more of preventive and educative approach than punitive and interventionist approach; (b) Setting priority to areas before intervention based on comprehensive study; (c) Coordination and cooperation with other organs having similar objectives; (d) Well studied, cost effective and flexible approach to intervention; (e) Facilitation of industrial self-regulation; and (f) Statutory guidelines for alternative dispute resolution mechanisms (ADR). ${ }^{22}$ The first three schemes are briefly presented below.

\subsection{Adoption of less punitive and more lenient, educative and responsive enforcement sanction}

The market is sensitive and does not need unnecessary intervention unless it fails to regulate itself. Hence, a competition and/or consumer protection authority needs to have guidelines which enable it to adopt less punitive and more lenient, educative and responsive enforcement sanction. ${ }^{23}$ According to Ayres and Braithwaite, a regulatory body needs to have access to hierarchy of enforcement sanctions that pursue the following stages of regulation:

- Stage 1: Education, Advice and Persuasion

- Stage 2: Written warning, oral warning

- Stage 3: Administrative fine, injunction, payment of damage, and finally

- Stage 4: License revocation/ Criminalizing

The stages resemble a pyramid whereby the first stage applies to the business community at large while the fourth stage is applied as a remedy of last resort in

\footnotetext{
${ }^{20}$ Ibid.

${ }^{21}$ See for example, CHOICE, Good Practices in Consumer Protection, A Review of 12 Australian Regulators, Available at $<\mathrm{http}$ ://www.choice.com.au, $>$ See also, Marcia, Pardo, <Chilean Legal and Institutional Arrangements for Consumer protection>, National Economic Prosecutor's Bureau Research Division, August, 2009, Telecomunication Management Group, <Legal and Institutional Framework for Consumer Protection>, ICT Regulation Toolkit, Module 6, February 2011, Available at $<$ http://www.ictregulationtoolkit.org >, Last visited on Oct. 10, 2014; WB, supra note 19; UNCTAD Model Law on Competition, United Nations, Geneva, 2000, Mehta, P. S., How to Build an Effective Competition Regime in Developing and Transition Countries, paper published under the '7-Up Project', CUTS Centre, No. 0301, 2003.

${ }^{22}$ Ibid.

${ }^{23}$ Ayres, I. and Braithwaite (1992), J. Responsive Regulation: Transcending the Deregulation Debate, New York, Oxford University Press.
} 
few cases. These stages show that priority should be given to education, advice and persuasion which are less costly, responsive and capable of bringing longlasting positive changes to the consumers by facilitating voluntary compliance of businesses with consumer protection rules. Criminal penalty and license revocation are thus expected to be applied only in cases where there are gross consumer violations and repeated non-compliance with the regulation.

\subsection{Setting priority regarding the areas of intervention based on comprehensive study}

Determining the priorities regarding the areas of intervention is another key strategy for the effective implementation of consumer protection. It must be based on comprehensive study because unnecessary interventions in the market without study or based on inadequate study may result in negative effects to the consumers. Therefore, an enforcing agency should apply its consumer protection enforcement resources to areas of high consumer risk. ${ }^{24}$ The enforcing agency should select the type of enforcement option most likely to deter unlawful behaviour, taking into account the likely extent of potential impact on consumers, that is, ensuring that enforcement action is proportional to the risk and level of harm. Before prioritization, there should be risk assessment on the effect of non-compliance with consumer protection and/or competition regulation on general consumer welfare. The risk assessment is the initial step in the analysis of the compliance behaviour of the target group. ${ }^{25}$ OECD indicates the importance of prioritization of regulatory enforcement:

... Effective compliance can only be achieved if regulations are realistic and adequate for a given country - and no amount of enforcement will make unrealistic rules work. At the same time, in order for enforcement activities to deliver their expected results, they need to be properly resourced - which means that risk-based strategic planning must be conducted to ensure that sufficient resources are available to address key risks, and that overambitious aims are not ascribed to enforcement agencies. Prioritization is essential to ensure that results are achieved where they are most needed. ${ }^{26}$

In assessing the risk, factors such as the degree of seriousness of consumer harms, cost of enforcement/intervention/ and legal duty are the most important

\footnotetext{
${ }^{24}$ CHOISE, supra note 21 , at 33

${ }^{25}$ European Community Forum for Exchange of Information on Enforcement(ECFEIE), Strategies for enforcement of Regulation (EC) no. 1907/2006 concerning the Registration, Evaluation Authorisation and Restriction of Chemicals (REACH) Paper Prepared on $3^{\text {rd }}$ meeting of E.C. 2-4 December 2008, Available at $<$ http://www.strategies_enforcement_reach_pdf $>$. Visited on 9 October 2015

${ }^{26}$ OECD (2013), Best Practice Principles for Improving Regulatory Enforcement and Inspections, Draft Report Submitted to the Public Consultation.
} 
which should be followed by prioritization thereby making a prudent choice as to the enforcement options. Priority should be given to an enforcement option which is more responsive to compliance by the target group and less restrictive to free trade. ${ }^{27}$

\subsection{Coordination and cooperation among institutions entrusted to enforce consumer protection}

Coordination and cooperation of the authority in charge of consumer protection competition with other organs having similar objective is crucial for the proper implementation of consumer protection by avoiding conflict of interests between regulators. ${ }^{28}$ As consumer protection legislations are enforced by various organs having similar objective, concurrent jurisdiction may result in two or more agencies wanting to address the same issue or none of the agencies addressing an issue because each mistakenly believes that the other is pursuing the matter. ${ }^{29}$ There is, therefore, a risk of either a duplication of effort or issues falling through the cracks.

Coordination among regulatory organs is thus indispensable. Gustavo Adolf, notes the problem of jurisdictional overlap among regulators and gaps in collaboration:

While it is clear that there exists the problem of jurisdictional overlap in the issue of the competency for regulated sectors, the greatest problem is that of inter-institutional collaboration among officials in public administration who should support one another in the benefit of a common end. ${ }^{30}$

Therefore, there should be a legal boundary which demarcates the jurisdiction and practical steps in order to reduce the likelihood of such occurrences. Meanwhile there is the need for establishing a line of communication between these bodies so that their respective activities are discussed so as to take advantage of the synergies and to reduce overlaps and inefficiencies. This requires maintaining a close relationship which involves frequent discussions and collaboration between or among concerned regulators.

\footnotetext{
${ }^{27}$ Ibid, p. 24.

${ }^{28}$ David Miller, Competition and Consumer Protection: The Relationship in Practice in Jamaica, $5^{\text {th }}$ IDRC PRE-INC Forum on Competition and Development, Available at $<\mathrm{http}: / /$ www.competition_and_consumer_protection_the_reletionship_in_practice_in_Ja maica_Mr_David_Miller.sflb.ashx.pdf $>$

${ }^{29}$ Ibid.

${ }^{30}$ Gustavo Adolf, Institutional Challenges to Competition Policy in Panama, Available at $<$ www.PANAMA_institutional_challenges.pdf > last visited on 10 October 2014.
} 


\section{Common Features and Practices of Effective Institutional Design for Consumer Protection Law Enforcement}

There is no common model for the assessment of effective institutional design for consumer protection because the design, powers, degree of autonomy, composition and jurisdictional authority depends on a specific country's legal, political and institutional framework. ${ }^{31}$ There are three general institutional approaches which are commonly used in different countries with regard to designing their respective institutional framework for an authority that regulates competition or/and consumer protection. ${ }^{32}$ They are (a) Single Authority /Partially Integrated Authority Model, (b) Hybrid Authority/Integrated Authority Model, and (c) Two Separate Institutions/Separate Agency Model.

\section{a) Single Authority /Partially Integrated Model/}

As Ceres notes " $[t]$ he partially integrated model combines the enforcement of competition law and some specific parts of consumer law related to information, such as rules against deception or misleading advertising". ${ }^{33}$ Where a competition law also includes provisions relating to consumer protection issues (hybrid law) and if a single authority is entrusted to enforce the law, then the system of such design is called Single Authority System or Partially Integrated Authority Model. ${ }^{34}$ In this approach, the main law is the competition law and the main power and function of the authority are related to competition promotion. But only few provisions dealing with consumer protection are included to be enforced by the authority. Some of the countries that have hybrid law and single or partially integrated enforcing agent are Zambia (Zambian Competition Commission), Zimbabwe (Anti-Corrupt and Anti-Monopoly Programme), Tanzania (Fair Competition Commission), Albania (Competition Law Authority), Algeria (Competition Council), Egypt (Egyptian Competition

\footnotetext{
${ }^{31}$ See World Bank, supra note 19.

${ }^{32}$ The three types of classification is made by the researcher based on information from sources like: Kati Cseres, Institutional Design for the Enforcement of Competition Law and Consumer Protection Law, Amsterdam Centre for Law and Economics, University of Amsterdam. See also Kati, Cseres, Integrate or Separate - Institutional Design for the Enforcement of Competition Law and Consumer Law (April 11, 2013). Amsterdam Law School Research Paper No. 2013-03; Amsterdam Centre for European Law and Governance Research Paper No. 2013-01. Available at SSRN:

$<$ http://ssrn.com/abstract $=2200908>$ visited on 11 October 2014; see FTC, International Activities: Competition and Consumer Protection Authorities Worldwide from $<\mathrm{http}: / /$ www.ftc.gov $>$, (Last modified lists on Wednesday 1, 2010), visited on February 20, 2015, Cornelius Dube supra note 15.

${ }^{33}$ Kati Cseres, ibid.

${ }^{34}$ Dube, supra note 15, p. 7.
} 
Authority), Italy (Autorita Garante della concorrenza e del Mercado) and Cameroon. $^{35}$

\section{b) Hybrid Authority (Integrated Authority)}

The integrated model, according to Ceres, "represents an agency with a double mission: responsibilities for the enforcement of both competition law and consumer protection law". 36 Hybrid authority occurs where there are two different laws on competition and consumer protection in a single or separate pieces of legislation, "but the laws are enforced by one authority". Ceres sates that "this kind of authority usually contains two divisions within a single authority where one of them deals with competition issues and the other one deals with consumer protection", and with regard to their hierarchy, "one authority may be designed to be subordinate to the other depending upon a country specific design choice". ${ }^{37}$ Australia (Australian Competition and Consumer Commission), Ethiopia (Trade Competition and Consumer Protection Authority), Bulgaria (Commission for Trade and Consumer Protection), Denmark (Danish Competition and Consumer Protection Authority), Barbados (Fair Trading Commission), Mongolia (Authority for Fair Competition and Consumer Protection), Philippines Bureau of Trade Regulation and Consumer Protection and Department of Trade and Industry), France (Directorate-General of Competition, Consumption and the Repression of Fraud), New Zealand (Commerce Commission), Panama (Authority for Consumer Protection and Competition Defense), Poland (Office of Competition and Consumer Protection) and Sri Lanka (Consumer Affairs Authority), are some of the counties following this approach. ${ }^{38}$

\section{c) Two Separate or Independent Authorities/Separate Agency Model/}

This occurs where there are two separate authorities for competition and consumer protection which are institutionally and functionally independent of each other. ${ }^{39}$ Competition authority handles issues related with competition while consumer protection authority handles consumer interests including interests under trade practice. Some of the countries following this system are Argentina (National Commission for Defense of Competition for Competition

${ }^{35}$ Cseres, supra note 32.

${ }^{36}$ Ibid.

${ }^{37}$ The trends in institutional design seem to house the consumer protection agency within the competition authority. Indeed, there appear to be far more countries housing their competition authorities with their consumer protection agencies - even though a separate department is created for each agency in most instances, for example Australia, Barbados, Canada, France, Jamaica, Japan, Malta, Papua New Guinea, Poland, the Republic of Korea, and the United States, to name a few.

${ }^{38}$ Cseres, supra note 32

39 Ibid. 
Promotion and Undersecretary of Consumer Defense for Consumer Protection), South Africa (the Competition Commission and the Tribunal for Competition Act, while the National Consumer Commission enforces the Consumer Protection Act), Canada (Competition Bureau Canada and Competition Tribunal for Competition and Office of Consumer Affairs for Consumer Protection), Costa Rica (Commission for Promotion of Competition for Competition and Directorate for Consumer Support for Consumer Protection), Finland (Finish Competition Authority for Competition and Consumer Agency and Ombudsman for Consumer Protection). ${ }^{40}$

\section{Factors Determining the Choice of the Designs}

Several factors determine the choice of a particular design over the others which include country size, resources and expertise. ${ }^{41}$ It is normally recommended that hybrid agencies are more appropriate for small economies. ${ }^{42}$ Hybrid laws and agencies also save resources, and are also recommended for poor countries. But the main disadvantage of this system is an inefficient balance of focus, skewed towards consumer protection matters. ${ }^{43}$ Because of the nature and frequency of consumer related complaints in these countries much emphasis is placed on consumer protection. Competition matters are often times, not given the level of attention and dedication that is necessary ${ }^{44}$. Moreover, absence of perfect or total complementarities between the competition and consumer protection policies may create difficulties in their implementation by one agency such as conflicts that can possibly occur during price controls. ${ }^{45}$ It is also said that enforcement might not be easy where one regulatory authority is in charge of implementing the consumer protection and the competition policies because this can imply a multiplication of the implementation gaps in the two laws. ${ }^{46}$

However, for effective enforcement, any type of design should be supported by a strong and efficient structural and organizational set up. To regulate effectively, the authority must create institutional frameworks that provide structural, political, and budgetary independence, as well as sufficient competence and the necessary organizational structure to carry out its functions. $^{47}$

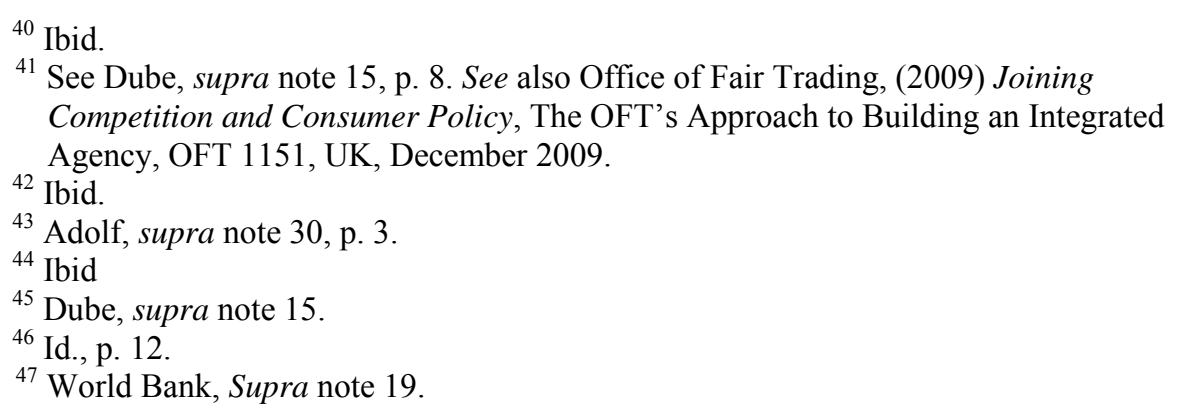


UNCTAD Model Law on Competition advocates that the most efficient type of administrative authority is one which is a quasi-autonomous or independent body of the government with strong judicial and administrative powers for conducting investigations and applying sanctions. ${ }^{48}$ In addition, the Centre on Competition, Investment and Economic Regulation (hereinafter referred to as 'CUTS') has identified independence, human and financial recourses as the most important factors underpinning the development of successful national competition or/and consumer protection institutions. ${ }^{49}$ Likewise, the World Bank recommends that governments need to ensure the independence of the competition authority ${ }^{50}$.

In settings of developed competition culture, a competition authority is expected to be financially and institutionally independent and accountable to parliament or the public even though some transitional and emerging countries have made their competition authority accountable to government agencies. ${ }^{51}$ East Asian countries like China, Korea, Singapore, Indonesia and Japan in a one or another way make their competition authority accountable to their respective executive bodies; ${ }^{52}$ the same applies to most of the African countries for example, Tanzania, Zambia, Uganda, Ethiopia ${ }^{53}$.

Decentralization of consumer protection enforcement to the level of local authority can also be a major factor that affects the proper implementation of the protections. In India, for example, the consumer protection authority has three tiers, i.e. at the - National level (The National Commission), state level (State Commissions) and district level (District Forums) ${ }^{54}$. Accordingly, $84.57 \%$ of the complaints are lodged and solved by the District Forums. ${ }^{55}$

\footnotetext{
${ }^{48}$ See Article 8, paragraph 121 of UNCTAD Model Law on Competition, Geneva, 2000.

${ }^{49}$ CUTS, Towards a Healthy Competition Culture, Jaipurs Printers P.Ltd, India, 2005.

${ }^{50}$ World Bank, Building Institutions for Markets, World Bank Development Report, Oxford University Press published for the World Bank, 2002, at pages 141-142.

${ }^{51}$ Maher M. Dabbah (2010), Competition Law and policy of developing countries: A critical assessment of the challenges to establishing an effective competition law regime, Queen Mary University of London, School of Law Legal Studies Research Paper No. $53 / 2010$.

${ }^{52}$ Pradeep S. Mehta (2002), Competition Policy in Developing Countries: An Asia-Pacific Perspective, Bulletin on Asia-Pacific Perspectives. Bangkok)

${ }^{53}$ Abebe A.,Alemu J. and Jambo B. (2006), Competition Scenario in Ethiopia: Consumer Protection Perspective."CUTS-CENTER, (August, 2006).

${ }^{54}$ Manoj Pandey (2010), Consumer Protection in India, Paper Presented by the Directory General of Competition Commission of India on 26th April 2010, New Delhi, India.

${ }^{55}$ Id., p. 18.
} 


\section{The Challenges of Limited Competition in the Enforcement Framework of Consumer Protection}

In a market economy, consumer protection is mainly enforced through the promotion of competition and by prohibiting anti-competitive practices and behaviour. ${ }^{56}$ Existing studies have shown that competition is a cornerstone for free market economy. ${ }^{57}$ Ethiopia has adopted free market economic policy since $1991^{58}$ and introduced the Trade Practice Proclamation in $2003^{59}$ which was later amended in 2010 and 2014. Four common anti-competitive market practices are prohibited under a competition law of most countries, and they are also adopted under the Ethiopian TCCPP. ${ }^{60}$ These are: Anti-competitive agreements, abuse of dominance, unfair competition and merger/Acquisition. ${ }^{61}$ These practices stifle competition in the market.

Although Ethiopia has enacted and amended laws that prohibit anticompetitive practices and behaviours, the level of competition in the country has been very low. ${ }^{62}$ Existing studies and empirical evidence show the prevalence of anti-competitive practices. ${ }^{63}$ Especially, anti-competitive agreements have been identified as the most prevalent anti-competitive practices that affect consumers

\footnotetext{
${ }^{56}$ Max Huffman supra note 5, p. 8. See also Abebe, Asmare, Alemu Jotie and Others, supra note 53 .

${ }^{57}$ Ibid.

${ }^{58}$ See Industrial Development Strategy of Ethiopia prepared in 1994.

59 The 2003 Trade Practice Proclamation, supra note 8.

${ }^{60}$ See articles 5-13 of the TCCPP, supra note 12.

${ }^{61}$ Ibid.
}

${ }^{62}$ All competition laws; i.e., the 2003 Trade Practice Proclamation, supra note 8, the 2010 Trade Practice and Consumer Protection Proclamation, supra note 11, articles 5-21 and the new 2014 Trade Competition and Consumer Protection Proclamation, supra note 12 article 5-13 prohibit the anti-competitive practices and behaviours. Interviews with traders, enterprises and consumers, Feb. 2-5, 2014, Hawassa City \& on January 30-36 in Addis Ababa City, Ethiopia. See also the study conducted by Abebe Asmare, Alemu Jotie and others, supra note 53.

${ }^{63}$ See for example, studies conducted by Roberto Zavatta and Samuel Feyisa, Baseline Survey on Competition and Market in Ethiopia, Private Sector Development Hub/Addis Ababa Chamber of Commerce and Sectorial Associations, 2009; Fikremarkos Merso, Imeru Tamirat Yigezu and Others, Review of the Legal and Institutional Framework for Market Competition in Ethiopia, Private Sector Development Hub/Addis Ababa Chamber of Commerce and Sectorial Association, 2009; World Bank (2006), Report on Investment Climate Survey for Ethiopia; Interview with Merkebu Zeleke, Director General of Federal Trade Competition and Consumer Protection Authority, on March 2, 2015; Interview with Bruktawit Walelign, Expert in Regulatory Work Process of Ministry of Trade on Feb. 29/2015. 
negatively ${ }^{64}$. The anti-competitive agreements may have one of the following three forms; first, price fixation/cartel like arrangements second, hoarding and price gouging third, exclusive distribution arrangements. ${ }^{65}$ Price fixing is the most prevalent in Ethiopia and it needs attention and severe sanction. ${ }^{66}$ Prices of goods and services are usually agreed by the traders including trade associations regardless of the quality of the products and services. ${ }^{67}$

Various views are forwarded regarding the possible causes for limited competition in Ethiopia? Maher M. Dabbah has identified involvement of government in the local market, political factor (the level of dedication of government to enhance free market economy), and institutional problem to be causes for limited competition in developing countries. ${ }^{68}$ Moreover, Fikremarkos Merso, Imeru Tamirat \& others have identified public sector dominance, price control, transparency in governments procurement and privatization, distorted financial market, inconsistent tax administration and business registration, unfair competition from party-affiliate enterprises and lack of awareness among business community and enforcers as some of the main causes for limited competition. ${ }^{69}$ According to Roberto Zavatta and Samuel Feyisa the problem of limited competition in Ethiopia, is among other things, attributable to market concentration, public sector dominance, (lack of involvement of) foreign investors and prevalence of anticompetitive practices. ${ }^{70}$

Although various studies state the prevalence of anti-competitive practices as one of the causes which have stifled the competition in Ethiopia, they fail to directly indicate the contributory sources for the prevalence of such practices. I argue that failure of proper law enforcement also contributes to the prevalence of the anti-competitive practices of business communities.

Firstly, since the establishment of the Trade Practice Investigation Commission (TPIC) in 2003 up to the present Trade Competition and Consumer Protection Authority (TCCPA), no cases on anti-competitive agreements have

${ }^{64}$ Roberto Zavatta \& Samuel Feyisa, Id., at 103, Fikremarkos Merso, Imeru Tamirat and Others, Id. at 57, interviews with Merkebu Zeleke, Bruktawit Walellign, \& interview with Traders and Consumers in Addis Ababa \& Hawassa Cities, supra note 63.

${ }^{65}$ Roberto Zavatta \&Samuel Feyisa, Id., pp. 102-103.

${ }^{66}$ Ibid.

${ }^{67}$ Interview with 15 fruit selling small and micro enterprises ("Associations") and 15 injera selling traders in Hawassa City on 4/08/2012, 4/12/2013 and 4/4/2014. See also Interviews with Merkebu Zeleke \&Brukitawit Walelign, supra note 63. As a consumer, prevalence of collusive price fixations are also evident from the writer's daily life experiences and observations.

${ }^{68}$ Maher M. Dabbah, supra note 51, pp. 12-15.

${ }^{69}$ Fikremarkos Merso and Others, supra note 63, pp. 53-56.

${ }^{70}$ Roberto Zavatta \& Samuel Feyisa, supra note 63, pp. 93-104. 
been entertained by the agencies and other organs. ${ }^{71}$ Except for cases of 'hoarding' against which the Ministry of Trade and some of the regional Trade and Industry Bureaus, have taken serious measures, there is no evidence that show measures taken against prevalent anti-competitive business practices. ${ }^{72}$

Merkebu Zeleke, the Director General of the TCCPA, said that the authority has immensely been working on awareness creation. He added that the authority has identified target groups for its awareness creation works like consumers, business community, investors and judges. He also said that the authority has been effectively using different the media, i.e. ETV, National Radios programs, pamphlets, brochures to create public awareness and public opinion and complaints, including access to a free telephone line, 8478. Although the educative and informative approach of the authority is commendable, it is also necessary to apply the law enforcement approaches against anti-competitive practices that are typically associated with undue profit seeking or opportunistic behaviour than lack of awareness. ${ }^{73}$ Regardless of the awareness creation works, increase in cartel arrangements from time to time call for another form of intervention. $^{74}$

Secondly, with respect to regions, there is no clear mandate given to regional governments to enforce anti-competitive laws. Part of this problem emanates from lack of decentralization of consumer protection enforcement as it will be discussed under subsequent section. However, it is to be noted that such measures should be prudent, highly selective and based on concrete evidence because discretionary measures can open doors for corruption and unduly harm the private sector thereby causing scarcity in supply which, in effect, worsens the burden on consumers.

\section{The Gaps in Institutional Framework in the Enforcement Framework of Consumer Protection}

With the enactment of the Trade Competition and Consumer Protection Proclamation No.813/2014 (TCCPP), different organs have been established and entrusted with the powers and duties to enforce it. These are: The Federal Trade

${ }^{71}$ See The Trade Practice Investigation Commission of Ethiopia, Four Years Performance Report of the Ethiopian Trade Practice Investigation Commission prepared on 24 September 2008 (2004-2008); Interview with Merkebu Zeleke who was the Director General of both former TPCPA and the present TCCPA, supra note 63.

72 Interview with Representative of Regulatory Department, Ministry of Trade on Feb 23/2015 and Interview with Southern Nation, Nationalities and People Region Trade and Industry Bureau on January 28/2015.

${ }^{73}$ Roberto, Zavatta \&Samuel Feyisa, supra note 63, p. 102.

${ }^{74}$ Merkebu Zeleke, supra note 63, and Interview with consumers and business community supra note 63. 
Competition and Consumer Protection Authority (hereinafter called the "Authority"), Federal Trade Competition and Consumer Protection Appellate Tribunal, Regional Consumer Protection Judicial Organs and Appellate Tribunals, Ministry of Trade (MoT) and Regional Trade \& Industry Bureaus (RTBs) and Courts both at federal and regional levels.

\subsection{The Trade Competition and Consumers Protection Authority: Gaps in structure and composition}

The TCCPP has established the Trade Competition and Consumer Protection Authority as an autonomous federal organ accountable to the MoT (art. 27). The Authority is headed by a Director General \& Deputy Director General to be appointed by the Prime Minister upon recommendation by the MoT and the Authority is to be composed of judges, investigative officers, prosecutors and other staff (art. 28). The Authority shall have its head office in Addis Ababa and may establish branch offices elsewhere as may be necessary (art. 29). The Proclamation also envisages the establishment of regional consumer protection judicial organ (art. 34).

One of the best practice principles for improving regulatory enforcement is the involvement of stakeholders in enforcement and compliance endeavours. ${ }^{75}$ Market forces, the private sector and civil society support compliance and enforcement. These forces should thus be explored wherever possible because the problems cannot be addressed solely through inspections and enforcement thereby necessitating many other means of attaining the regulatory objectives. ${ }^{76}$

The TCCPP has established the Authority without providing for representation of stakeholders especially, from the private sector and consumers. ${ }^{77}$ The Proclamation has repeated the mistake made under the 2010 Proclamation. In this regard, it is plausible to say that the 2003 Proclamation, in spite of gaps in its implementation, was better than the subsequent two proclamations ${ }^{78}$ The failure to provide for the representation of stakeholders in the Authority can contribute to challenges in enforcement because competition and consumer protection in a market economy involve the interests of the business community and consumers in addition to the government.

${ }^{75}$ OECD, supra note 26, p. 5.

${ }^{76}$ Ibid.

${ }^{77}$ There is no a single provision dealing with the representation of the stakeholders in the TCCPP.

${ }^{78}$ Article 13(1) of TCCPP provides for the representation of private organs, governments and consumers association. However, practically, all the members of the former Investigation Commission were from high ranking government officials (interviews with the former officials of the Commission). 
The role of the government should be facilitation of the market with some prudent interventions when the market fails ${ }^{79}$. Failure to recognize the representation of the private sector in the enforcement of competition and consumer protection will inevitably pose a huge challenge, primarily, to the private sector and, ultimately, to the consumers. There are views which state the dominance of endowment-owned businesses, and a substantial regional development organizations in Ethiopia's economy. ${ }^{80}$ As an expert in the Addis Ababa Chamber of Commerce and Sectorial Association (AACCSA) noted:

The problem lies with the economic structure of the country... the question should be 'who owns the economy?'...there is not enough playing field for private sector in our country. The large and medium scale economy are controlled by either the public sector or the political party affiliated enterprises... ${ }^{81}$

According to the legal advisor of the Ethiopian Chamber of Commerce and Sectorial Associations (ECCSA) private sector representation in the Authority would encourage voluntary compliance by business persons to consumers' protection regulations because it makes the business community own the issues of consumer protection. ${ }^{82}$ Moreover, most of the respondents from the private sector and Consumers' Protection Association replied that their exclusion is adversely affecting their interest in the economy. ${ }^{83}$

Biru Olbamo, the former Secretary of the Trade Practice Investigation Commission, stated that there is no explicit provision as to the representation of the private sectors and consumers in the Authority. He further noted that the government can take such representation into consideration while structuring the Authority as long as there is no prohibition to that effect. According to another respondent from the legal department of the MoT the exclusion of the aforementioned members from the Authority may not by itself be a problem,

79 See the 1994 Agricultural-Led Industry Policy of Ethiopia (ADLI). The ADLI considers the private sector as an engine of the nation's economy. Interview with officials of Addis Abeba Chamber of Commerce and Sectorial Association, Ethiopia Chamber of Commerce and Sectorial Association, and Ethiopian Consumers Association on Feb. 1215, 2013. All the interviewees believe in the need for the representation of the private sector and consumers. See also Industrial Development Strategy of Ethiopia prepared in 1994. One of the seven core principles of the working policy of Ethiopia, "Agricultural Development Led-industrialization" (ADLI), is making the private sector the engine of the economy.

${ }^{80}$ Sarah, V. and Mesfin, G. (2011). Rethinking Business and Politics In Ethiopia, Africa, Power and Politics Research Paper no.02, 2011.

${ }^{81}$ Interview with a high ranking expert in AACCSA who did not consent to the disclosure of his name and identity, May 2, 2013.

${ }^{82}$ Interview with a legal advisor of ECCSA, Jan 10, 2014

${ }^{83}$ Interviews with consumers and business persons in Hawassa March 3-6, 2014. 
and he added that what rather matters most is that decisions of the Authority are given in accordance with the law.

There is no certainty as to the practicability or otherwise of the representation of the private sectors and consumers in the Authority. All members of the 2003 Investigation Commission were from the government even while the legal provision of Proclamation No. 329/2003 provided for representation of the private sector and consumers' association. ${ }^{84}$ The same holds true for the former Trade Practice and Consumer Protection Authority where all members of the Authority were from the government. Some developing countries embody the details of such representation in their legal frameworks. ${ }^{85}$ Malawi, Egypt, Zambia and South Africa are some examples of African countries which have detail legal frameworks dealing with the representation of various stakeholders in their competition and/or consumer protection authorities. Denmark, Switzerland and Swaziland are also countries whose competition laws have legal provisions dealing with mandatory representation of stakeholders in their competition authority.

In addition to gaps related with lack of representation of the private sector and other stakeholders, there is another challenge that regional states in Ethiopia do not yet have their independent consumer protection law; nor do they have independent institutional frameworks for implementation. ${ }^{86}$ Even though the law envisages the establishment of a regional consumer protection judicial organ, it does not give administrative power to the organ; nor does it give the power to investigate and institute action against violators. ${ }^{87}$ The law also envisages the establishment of branches of the federal authority which have not been put into effect until now thereby leaving consumers in the regions outside the ambit of the envisaged protection. ${ }^{88}$

According to the FDRE constitution, consumer protection is not under the exclusive jurisdiction of the federal government, and matters that are not exclusively given to the federal government fall under the ambit of regional

\footnotetext{
${ }^{84}$ Supra note 78.

${ }^{85}$ CUTS, 2007, From the Bottom Up, Available at <www.cuts_international.org $>$, Visited on 12 September, 2014. See also, article 13 of the Egyptian Consumer Protection Law, Enacted by Law No. 67, 2006. It provides for the representation from General Association of Chamber of Commerce, Association of Egyptian Industry, The Special Union of Associations for Consumer Protection and Central Consumers and Cooperative Association in Egyptian Consumer Authority.

${ }^{86}$ Except for some sort of work processes established by the regions under the regional Trade Industry bureaus, there is no independent consumer protection authority or agency established by regions.

${ }^{87}$ See article 34 of the TCCPP, supra note 12.

${ }^{88}$ Id., art 29.
} 
powers. Cconsumer protection, as strongly argued, is not a commercial, but rather a civil matter. ${ }^{89}$ Though, arguably, the new law is said to have recognized consumer protection issues as regional matter ${ }^{90}$, it still does not recognize the power of the regions to enact their own consumer protection laws. This does not go in line with the Ethiopian federal system. ${ }^{91}$ The new law seems to have adopted executive federalism approach where the federal law maker enacts the law and regional governments apply the law made by the federal government. ${ }^{92}$ Indeed, this is not envisaged to be a characteristic feature of Ethiopian federalism. ${ }^{93}$ In fact, one may argue that regional states do not need such recognition under federal law as their power is set out in the FDRE Constitution, and in effect, they can act with or without the federal consumer protection law's recognition of their powers.

However, this argument is not without challenge when we observe the existing constitutional set up of regional states and the practices in Ethiopia. According to almost all of the regional constitutions in Ethiopia, it is provided that the laws enacted by the regional councils should not contradict with federal laws and FDRE Constitution (See article 51:1 of SNNPR Constitution, article 49:1 of Amhara Region Constitution, article 51:3(3:1) of Gambela Region Constitution, article 47(3)(a) of Afar Constitution, article 49(3)(a) of Oromiya Constitution and article 49(3)(a) of Somali Regional State Constitution). This might be one of the reasons for the failure of the regional states to enact their own consumer protection laws.

\subsection{Institutional mandate of the Ministry of Trade and Regional Trade Bureaus}

The Ministry of Trade (MoT) and Regional Trade \& Industry Bureaus (RTBs) are the most important organs in connection with the implementation of consumer protection under the TCCPP. According to article 23(5), MoT and RTBs shall have power to implement part of the Proclamation which deals with consumer protection except some of the provisions which are incumbent upon the Authority. This mandate is given to these organs mainly because matters of consumer protection need interventions of government in favour of the

${ }^{89}$ Interview with Ato Merkebu Zeleke, the General Director of the TCCPA, on 21/01/2015. According to Merkebu, the law recognizes the consumer protection matter as a civil matter. See also the discussions in the Draft Trade Competition and Consumer Protection Proclamation, 2014.

${ }^{90}$ Ibid.

${ }^{91}$ According to the FDRE constitution, Ethiopian federalism follows a horizontal system and all the three organs of the government: legislative, executive and judiciary in both federal and regional level have equal power in their respective spheres. See article 50 (8).

${ }^{92}$ See for example are articles 37(3), 23(5), 47(2) \& 4(1) of TCCPP, supra note 12.

${ }^{93}$ See FDRE Constitution, articles 50(8) and 52. 
consumers where the market fails. ${ }^{94}$ The MoT and RTBs are government organs connected with trade in federal and regional governments respectively. This can be seen from the present Ministry of Trade Establishment Proclamation No. $691 / 2010$ which defines the powers and duties of executive organs of FDRE government. ${ }^{95}$ Article 21 of Proclamation No. 691/2010 provides that the Ministry of Trade has the power to promote the expansion of domestic trade and take appropriate measures to maintain lawful trade practices.

The Ministry of Trade (MoT) has the power to issue directives and public notices for the implementation of the Proclamation (art. 46), the power to recommend or nominate the Director General and Deputy Directors of the Authority and arguably ${ }^{96}$, judges of the Authority. The Ministry has the power to determine and apply price regulation and distribution of basic goods and services upon the approval of the Council of Ministers (arts. 25 and 26 respectively).

Regional Trade Bureaus (RTBs) are also given power to deal with the implementation of the Proclamation (art.23), duty to inspect any acts of hoarding or diverting of goods and to ban the distribution of goods and services that do not fulfil the standard of health and safety (art.23:1) \& cause the disposal of goods that are spoiled and are dangerous to human health and safety (art. 23:4).

The Ministry of Trade (MoT) and Regional Trade Bureaus (RTBs) are entrusted with the power to conduct investigation in connection with the implementation of the Proclamation and to regulate distribution of basic goods and services (art. 44). The MoT has also the power to issue public notice and directive for the implementation of the Proclamation, in addition to which it can initiate regulations to be issued by the Council of Ministers (art.55). The MoT, when it appears necessary, submits to the Council of Ministers its study on basic goods and services that shall be subject to price regulation for approval (art.46).

Generally, one of the most important aspects of the new Proclamation in this regard is its recognition of the power of regional states over consumer protection

${ }^{94}$ Display prices of goods and services, labels of goods, issuing receipts and other obligations embodied in part three of the proclamation are regulatory requirements.

95 See The Definition of Powers and Duties of the Executive Organs of the FDRE Proclamation, Proc. No. 691, 2010, Federal Negarit Gazeta, $17^{\text {th }}$ Year No. 1.

96 Article 38 (1) states that, "Each division of the adjudicative tribunal shall have one presiding and two other judges to be appointed by the Prime Minister." But this article does not address the question 'who nominates the judges to be appointed then?' It is plausible to argue that the MoT is the relevant organ for this function because, it is the relevant ministry to trade/market related issues (see also article 21); on the other hand, the MoT is given the power to recommend the director general of the Authority. 
matters, in spite of the ambiguity and inadequate empowerment as discussed below.

\subsection{Gaps related with inadequate empowerment of Regional Trade Bureaus}

Even though bringing the Regional Trade Bureaus (RTBs) into the picture in relation to the implementation of consumer protection in some areas under the Proclamation can be taken as a progress at least as compared with the former Proclamation, it does not sufficiently "empower" the RTBs so as to enable them effectively enforce consumer protection in their respective spheres. For example, the Proclamation does not empower the regional concerned bodies to regulate prices of basic goods and services. As the issue of power relationships between the federal government and regional governments fall outside the scope of this article, ${ }^{98}$ focus is made on the effect of denying RTBs of such power on the effective enforcement of consumer protection.

Under articles 25 and 26, the MoT is given the power to regulate prices of basic goods and services, and distribution of basic goods. By virtue of Article 25, MoT shall, when deemed necessary, "submit to the Council of Ministers its study on basic goods and services that shall be subject to price regulation and upon approval publish their list and prices in public notices". And according to Article 26, the Ministry "in consultation with other concerned government organs may determine the conditions of distribution, sale and movement of basic goods and services and, as may be necessary, order the business person to replenish the stock of the same".

As we may see from the above two provisions, regulating prices of basic goods and services, and the distribution of basic goods fall under the mandate of MoT without recognizing that RTBs have similar power. This may pose threat to the effective enforcement of the Proclamation for at least two reasons.

Firstly, regional organs are more relevant or closer to determine whether certain goods and services are basic or not depending upon the existing realities

\footnotetext{
${ }^{97}$ The writer is in doubt as to whether or not the parliament of the federal government of Ethiopia has power to "empower" the regional trade bureaus of the regional government. Consumer protection is a civil matter and not a commercial matter, and such matter is not explicitly given to the federal government under FDRE Constitution.

${ }^{98}$ Questions such as: (a) whether the relationship between the federal government and regional governments in Ethiopia is horizontal or vertical, (b) whether the federal government can play a supervisory role over the regional governments, (c) whether the federal lawmaking body can confer or deny to confer or impose duties on the regional executive bodies in relation to enforcement of the federal laws, (d) whether consumer protection is a federal matter or a state matter, and similar questions need further researches.
} 
in their respective regions. ${ }^{99}$ For example, "kocho" may be basic to SNNPR than 'Injera' which could be basic to Amhara or Tigrai regions or other regions. Prices may also differ depending upon different factors which are not evenly distributed throughout all regions. Arbaminch Town Trade \& Industry Bureau and Hosana Town Trade Bureau of the SNNPR may, for instance, set prices for some fruits deviating from the price caps determined by MoT. As Ato Yohannes Mima from SNNPR Trade Bureau Trade Practice Investigation and Research Department stated: "The Minstry of Trade fixes the prices of some of the basic goods taking into consideration the market situation in Addis Ababa which is the central market of the country and gives us the 'price caps' thus determined by the Ministry". He added that the Bureau "re-determines the prices set accordingly by taking different factors like, cost of transportation and other costs into account and apply them accordingly". He also said that "we have also the power to regulate the prices of some other basic goods and services which are not subjected to such regulation by the Ministry."

But the most important question here is whether the regional states have their own consumer protection laws. If they are enforcing the federal law, the Proclamation does not give power to RTBs to regulate prices of basic goods and services. In fact, there is no regional state in Ethiopia which has its own law and authority on consumer protection. ${ }^{100}$

Secondly, and in fact arguably, ${ }^{101}$ the issue of price regulation is not a competition law matter; rather it is regulation of consumer protection. And the issue of consumer protection is not under the exclusive jurisdictions of the federal government under the FDRE Constitution. ${ }^{102}$ In other words, the Regional Trade Bureaus should have been given power to make studies on price regulation of basic goods and services and submit the study to the regional state administration which is the appropriate counterpart of the Council of Ministers.

${ }^{99}$ Article 2(1) of the TPCPP defines basic goods and services to mean goods or services related to the daily need of consumers, the shortage of which in the market may lead to unfair trade practice. From this definition, we can see that there are no objective criteria to determine whether a certain good or service is basic or not.

${ }^{100}$ Interview with Merkebu Zeleke, the Director General of the Trade Practice and Consumer Protection Authority, 21/01/2015.

${ }^{101}$ It might be an arguable issue because commercial matter under the FDRE Constitution is classified as the federal matter and that the consumer issues we are raising here are related to market practices.

${ }^{102}$ See article 52(1) cumulative with 55 of FDRE Constitution (1995), Negarit Gazeta, Year 1, No.1, August 1995. 


\section{Challenges in Consumer Protection Enforcement Strategy through Price Regulation}

There are three types of price regulation strategies, namely (a) Direct price control, (b) Rate of Return Regulation (RRR), and (c) Price-cap regulation. Direct price control involves direct fixation of the prices of products and services by the regulator or government. ${ }^{103}$ Approval of price changes (increases $\&$ decreases) is made by government or by the regulator. ${ }^{104}$ Since price increases are usually politically unpopular, approval tends to be usually given with reluctance and delays. This is increasingly seen to be inappropriate in a market economy. This kind of price regulation is unpopular, anti-competitive, interventionist, outdated and does not take different factors such as inflation into consideration. ${ }^{105}$

The second price regulation strategy is Rate of Return Regulation (RRR) which essentially involves the limitation of profits at a 'reasonable' level (i.e., determining profit margin for traders or business organizations) ${ }^{106}$ after having considered necessary costs. The experience in the US, for example indicates that the use of RRR may involve long arguments as to what a 'reasonable' rate of return is. ${ }^{107}$ It may also involve detailed and long arguments over what costs were necessarily (and efficiently) incurred. ${ }^{108}$

The third strategy is price-cap regulation whereby a service provider's or seller's price increases would be limited to the rate of inflation less an agreed " $X$ " factor (based in principle on expected productivity improvement of traders or business organization). ${ }^{109}$ Essentially the price cap scheme restricts price increases to 'CPI - X' where: CPI (Consumer Price Index) is the inflation rate. ${ }^{110}$ If inflation is, for example, $8 \%$ and the " $X$ " factor is set at $3 \%$ the price cap becomes " $8 \%-3 \%$ ". This means, price increases will be restricted to no more than $5 \%$ per year for the duration for the application of the formula. In principle, there would be no restriction on the level of profits thereby making it less intrusive, more popular and conventional.

\footnotetext{
${ }^{103}$ Patrick Xavier (2012). Pricing Strategies in the Context of Price Regulation, Discussion Paper School of Business, Swinburne University, Melbourne, Australia.

${ }^{104}$ Ibid.

105 Ibid.

106 Ibid.

${ }^{107}$ Ibid.

108 Ibid.

109 Ibid.

${ }^{110}$ Ibid.
} 
In January 2011, Ethiopia's Ministry of Trade made price regulation on 18 consumer goods. As discussed above. ${ }^{111}$ the Ministry fixed the prices on the goods based on 'Direct price control method. ${ }^{112}$ The Ministry announced its decision of price control on 'basic goods and services' in reaction to the inflation which it believed was "man-made inflation"113. Rice, imported milk, soap, beer, soft drinks, orange, banana, pasta and meat were among the commodities subjected to direct price control.

The TCCPP defines 'basic goods and services' as "goods or services related to the daily need of consumers, the shortage of which in the market may lead to unfair trade practice. ${ }^{114}$ From the legal point of view, it is arguable whether these items are basic goods. Secondly, goods like, injera, onions, and services like house lease or rent are more basic to Ethiopian consumers than the goods listed above. So, the regulation lacked "prioritization" with regard to areas of intervention.

Moreover, there were gaps in making a deep pre-intervention study. In particular, it did not take different factors affecting the prices of goods and services into consideration. As Zakarias Mekonen Yigzaw observed:

... producers/importers, suppliers, wholesalers and retailers were mostly not happy with the price ceiling measure because of many reasons; First, the price setting does not actually consider the cost factors arising from importing with hard currency, passing with different legal and transportation fees, labor and sales people as well as rent costs for shops and thus it barely makes them make profit. Second, even after price ceiling was made, it was not done uniformly. ... Thirdly, [there] were [businesspersons who felt] warned and frightened by the government while [they] were doing [contrary to] the 'Idea of Free market' .... . 115

Although the regulation was welcomed by consumers at its early phase, consumers themselves were not eventually happy because it caused complicated problems of shortage of items, poor quality service and unnecessary waste of

${ }^{111}$ See also Thomas Wold \& Grum Abebe (2013). Urban Food Retail in Africa: The Case of Addis Ababa, Ethiopia.

112 This approach does not take inflation into consideration. It is easy to fix the prices but difficult to apply them.

${ }^{113}$ The Former Prime Minister and other higher officials of Ethiopian government held that the 2011 inflation of prices of goods and services were attributable to the act of the business community (Source: www.ethiofirst.info.news last visited on May 2, 2013

${ }^{114}$ See Article 2:3 of the TCCPP, supra note 12.

${ }^{115}$ Zekarias Mekonnen Yigzaw (2011). "Effects of Recent Price Ceiling On the Demand and Supply of Agricultural Products: A case of Addis Ababa", School of Agriculture, Economics and Agribusiness, A case study report to supplement OER materials of Ag Share pilot project, Haramaya University, Ethiopia. 
time due to long queue at distribution points. ${ }^{116}$ This led to series of complications. For example, the initial fixed price for a litre of oil was ETB 16.50 which failed to materialize because cost of imported oil per litre without adding transportation, and loading and unloading cost was over ETB 20. ${ }^{117}$ Following negotiations and discussion between wholesalers, importers and the government, the price was re-adjusted to ETB 21.50 and then to ETB 24.50. Few days later, palm oil disappeared from the market. Once again, the MoT decided to collect all edible palm oil from importers who had ordered supplies at higher prices due to increase in international market. ${ }^{118}$ The MoT then tried to distribute the palm oil at a fixed price thereby organizing small consumers associations at kebele level. However, scarcity of oil persisted. ${ }^{119}$ These trial and error measures can, among other things, be attributed to lack of pre-intervention analysis or studies prior to the determination and application of the regulation.

\section{Conclusion}

Even though there are no uniform enforcement strategies and practices for consumer protection across the world, the pursuance of advocacy and preventive approaches are more effective in contrast to punitive and interventionist approaches. The consumer protection enforcement strategies that are advocated by many scholars include prioritizing the areas of intervention based on comprehensive study, flexibility and promotion of self-regulation, and coordination and cooperation of enforcing institutions with other relevant organs that have similar objectives. These effective strategies are adopted and applied in the competition and consumer protection enforcement frameworks of many countries.

International good practices show that depending upon country specific socio-economic and political realities, the common designs that are put into practice are the partially integrated authority model, integrated authority model and separate authority model. As briefly discussed in Section 2, each model has its own advantages and disadvantages. It is, however, to be noted that the model which is adopted should be supported by a strong and efficient structural and organizational set up.

Despite the progresses made by Ethiopia to bring about an effective consumer protection regime by adopting laws and establishing institutions, I

\footnotetext{
116 Ibid.

${ }^{117}$ Interview with wholesalers in Hawassa City On June 3, 2013.

${ }^{118}$ Fortune, "Government to Take Over Imported Palm Oil”, Vol.11, No. 569, Sunday, March 27, 2011.

${ }^{119}$ Observations made in Yirgalem, in Sidama zone and most places in Addis Ababa, Gulele sub-city (Menen and Shiro Meda).
} 
argue that the present enforcement framework has gaps because it failed to recognize the representation of major stakeholders such as consumers and business persons in the enforcement authorities while the existing reality and international practices justify their recognition. The inadequate emphasis given for competition promotion, failure to recognize representation of major stakeholders in the Consumer Protection Authority and failure to decentralize the consumer protection affairs are identified as the major challenges. Lack of extensive pre-intervention study, failure to give priority to areas of greater consumer risks and failure to take measures against anti-competitive practices of traders and business organizations are found to be the major practical failures of the enforcing institutions. These gaps have resulted in steadily increasing problems in the avenues of fair competition and consumer protection, which I argue are having some manifestations of crisis in consumer welfare.

The gaps and challenges discussed in this article thus call for amendments in the law to include mandatory provisions that require the representation of stakeholders, especially, consumers and the business community in the Authority. Since consumer protection is a civil matter than commercial, the respective regions can enact their own consumer protection law and establish an independent consumer protection institution for its enforcement. Moreover, for the proper determination and successful application of a price regulation, Regional Trade Bureaus ought to be empowered to regulate prices of basic goods and services in their respective regions. In regulating prices of basic goods and services, the conventional method i.e. price cap regulation approach (highlighted in Section 6) rather than the direct price control approach should be adopted by taking various factors into consideration. Prior to such intervention, however, institutions entrusted with the duty to enforce consumer protection regulations should conduct pre-intervention studies as to prioritization, determination, application and cost benefit analysis.

Mere focus on consumers indeed renders it difficult to bring about long term consumer welfare because a two-sided problem cannot be resolved from a single dimension. Needless-to-say, competitive markets deliver better protection to consumers than the 'benefits' accrued from protective government intervention in a non-competitive market. The enforcement framework should not thus solely target at a single dimension, but should rather maintain the balance between consumer protection and competition promotion. This requires the empowerment of enforcement institutions to enable them work more on the promotion of competition and at the same time take effective legal measures against anti-competitive practices. 